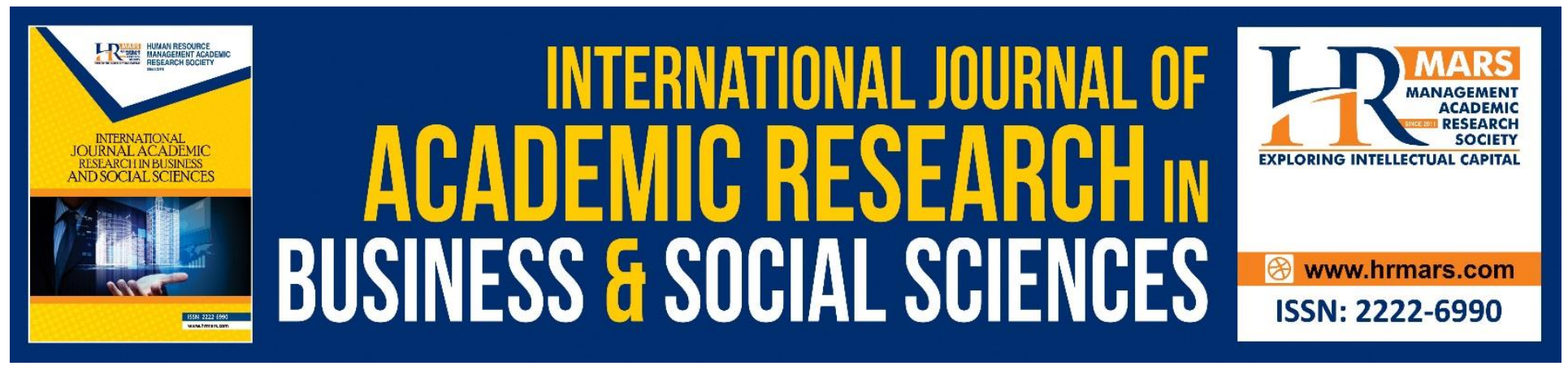

\title{
The Validity of the Critical Thinking Instrument in the TIG Welding Training Modules based on Project Based Learning (PBP) in the Subject (DJJ3032) of the Mechanical Workshop Practice 3 in Malaysian Polytechnic
}

Md Kharul Bin Rakib, Che Ghani bin Che Kob, Arman Shah \& Arasinah

To Link this Article: http://dx.doi.org/10.6007/IJARBSS/v9-i1/5325 DOI: $10.6007 /$ IJARBSS/v9-i1/5325

Received: 21 Dec 2018, Revised: 16 Jan 2019, Accepted: 21 Jan 2019

Published Online: 28 Jan 2019

In-Text Citation: (Rakib, Kob, Shah, \& Arasinah, 2019)

To Cite this Article: Rakib, M. K. Bin, Kob, C. G. bin C., Shah, A., \& Arasinah. (2019). The Validity of the Critical Thinking Instrument in the TIG Welding Training Modules based on Project Based Learning (PBP) in the Subject (DJJ3032) of the Mechanical Workshop Practice 3 in Malaysian Polytechnic. International Journal of Academic Research in Business and Social Sciences, 9(1), 18-25.

\section{Copyright: (C) 2019 The Author(s)}

Published by Human Resource Management Academic Research Society (www.hrmars.com)

This article is published under the Creative Commons Attribution (CC BY 4.0) license. Anyone may reproduce, distribute, translate and create derivative works of this article (for both commercial and non-commercial purposes), subject to full attribution to the original publication and authors. The full terms of this license may be seen at: http://creativecommons.org/licences/by/4.0/legalcode

$$
\text { Vol. 9, No. 1, 2019, Pg. } 18 \text { - } 25
$$

Full Terms \& Conditions of access and use can be found at http://hrmars.com/index.php/pages/detail/publication-ethics 


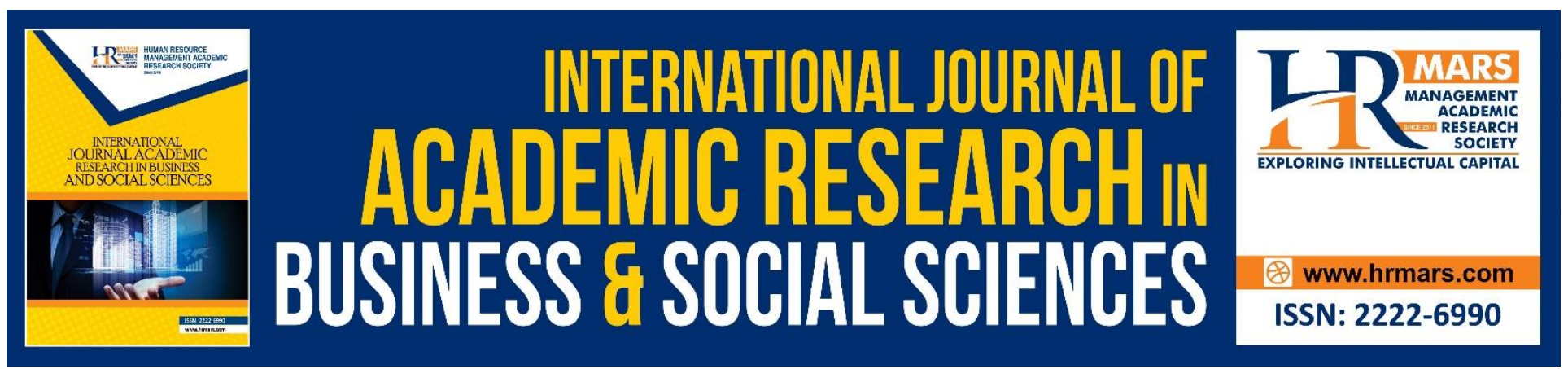

\title{
The Validity of the Critical Thinking Instrument in the TIG Welding Training Modules based on Project Based Learning (PBP) in the Subject (DJJ3032) of the Mechanical Workshop Practice 3 in Malaysian Polytechnic
}

\author{
Md Kharul Bin Rakib, Che Ghani bin Che Kob, Arman Shah \& \\ Arasinah \\ Universiti Pendidikan Sultan Idris (UPSI) \\ Email: mdkharul87@gmail.com
}

\begin{abstract}
This academic study is aimed accurately at the established validity of critical thinking questionnaires in the TIG Welding Training Modules based precisely on Project Based Learning (PBP) in the Subject (DJJ3032) of Mechanical Workshop Practice 3 in Polytechnic Malaysia. This study represents a quantitative approach that uses the survey method to influence an excellent opinion through a questionnaire related to the content of critical thinking. The research sample consists precisely of 8 vicariously experienced experts in the chosen field of welding in Malaysia. The findings show that this research instrument maintains the moral content validity.
\end{abstract}

Keywords: Content validity, questionnaire instrument, Critical Thinking, Mechanical Workshop Practice 3, Project Based Learning, Polytechnic Malaysia.

Introduction

The purpose of this academic study was precisely to validate the critical thinking questionnaire of the TIG welding training module based on Project Based Learning (PBP) in the academic subject (DJJ3032) of Mechanical Workshop Practice 3 in Polytechnic Malaysia.

Latterly, the ultimate challenges resolutely faced by the education organizations are precise to sufficiently develop critical thinking skills to properly accommodate the specific needs of potential employers for a skilled workforce in the local industry (Khan, 2015). In addition, the consistent findings of AbdulGhani(2012)found that engineers in Malaysia did not possess critical thinking skills. According to the academic studies by Azizi using the California Critical Thinking Skills Test (CCTST) instrument on the 100 final year students in four technical universities, 
typically exposed that the notable lack of considerable emphasis on the effective teaching of critical analytical skills in the engineering-based education system. According to the study by Mohd on the Intellectual Engineering graduates on Intellectual Engineering stated that significant differences were seen in Critical Thinking Skills. This means precisely that the present education system needs to accurately indicate a more holistic emphasis to all appropriate levels so that critical thinking skills can be properly applied from pre-school to university. In other words, Malaysian Polytechnic is undoubtedly among the prominent producers of engineers to discover the effective ways to overcome the problems of these critical graduates who accurately represent less critical thinking. It, therefore, shows that employers in the engineering sector in Malaysia need engineers who acquire critical analytical skills as well as other non-technical skills to support Malaysia to achieve the National Transformation 2050 successfully.

\section{Research Objective}

The validity of critical thinking questionnaire tools in the TIG Welding Training Modules based on Project Based Learning on the subject of Mechanical Workshop Practice 3 in Malaysian Polytechnic.

\section{Methodology}

This academic study is precisely quantitative using a survey method to identify the validity of the critical thinking instrument in the TIG Welding Training Module. In addition, the institute developed, needs to be reviewed by the field expert to obtain the validity of the instrument content in this study, the researcher conducts the validity of the critical content of critical thinking instruments to ensure the contents of the instrument are well-established and recognized quality.

The practical use of validity in the study is to accurately test the possible extent to which the accuracy of a measuring instrument studied in a study. According to Pallant (2007), validity refers to the extent to which a necessary tool used sparingly to measure the essential characteristics carefully studied in a study. This implies an instrument is considered to be valid and can be applied if it can measure what is supposed to be measured and an instrument or instrument of measurement is also valid when the construction of the tool meets or meets its function and objectives.

Simultaneously, according to Othman (2018), the validity is precisely a reliable accuracy marker of the academic study ie whether the study offers a realistic picture of the observed phenomenon studied or not. This validity process also needs to be done properly by responsible leading experts in the chosen field reasonably related to the exclusive content of the developed questionnaire. This coincides precisely with the accurate statement of Idris (2013) stating that to progressively increase the validity content of a research instrument, the academic researcher should eagerly seek views and constructive feedback from the expert to properly evaluate and ensure the essential elements in an effective instrument accurately represent the specific area to be studied. This is because the feedback and views of these experts are critically important for obtaining quality and acceptable institutions.

According to Anastasi (1997), the validity of the content accurately represents a systematic assessment of the excellent quality of an effective instrument. Therefore, it accurately measures the remarkable thing to be measured. Additionally, to ensure that the built-up is robust and applicable, 
the specific percentage of the content validity of the effective instrument should be sufficiently taken into account. This is because of the moral validity of the findings properly obtained based precisely on alleged facts and able to give correct justification (Idris, 2013).

The researcher has provided a complete copy of the TIG Welding Training Module which contains the introduction, objectives goals of the module, the basis of the theory used, the overall content and the attachment of the teaching aids. Critical thinking questionnaire instrument TIG welding module provided for comprehensive review and objective evaluation and specific recommendations by the independent panel. The selection of skilled groups in this study is based on expertise, experience and relevance with the contents of the instrument developed. In this study, the criteria for specialist selection are based on (i) expertise and knowledge in the field of TIG / GTAW welding. (ii) expertise and experience in the field of welding (iii) expertise and experience in language (iv) experienced practitioners or welders and (v) Malaysian Polytechnic welding and casting book makers. Experienced practitioners or lecturers in the field of welding are further defined by ensuring that they understand and implement teaching and learning in Malaysian Polytechnic. The list of expert panels is like table 1 below.

Table 1: Expert Panel Profiles

\begin{tabular}{|c|c|}
\hline Expert Panel & Biodata and experience \\
\hline P1 & $\begin{array}{ll}\checkmark & \text { Malaysian Polytechnic Lecturer in welding } \\
\checkmark & \text { Teaching in the field of welding for } 25 \text { years until now }\end{array}$ \\
\hline P2 & $\begin{array}{l}\text { - Malaysian Polytechnic Lecturer in welding field } \\
\text { - Experienced teaching welding approximately } 10 \text { years } \\
\text { - Has been a producer of welding courses at Community } \\
\text { College }\end{array}$ \\
\hline P3 & $\begin{array}{ll} & \text { Polytechnic lecturer in welding field } \\
\circ & \text { Teach welding workshops about } 13 \text { years } \\
\circ & \text { Experts in arc, gas, TIG and MIG welding bases from } 2005 \text { to } \\
& 2018\end{array}$ \\
\hline P4 & $\begin{array}{l}\text { - Welding lecturer in polytechnics } \\
\text { - Experienced welding work in the continental sime tire for } 10 \\
\text { years and taught in welding field at Sarawak Polytechnic for } 5 \\
\text { years and then pursued polytechnics in behrang for } 4 \text { years } \\
\text { until now } \\
\text { - Experience in the welding field for about } 10 \text { years. }\end{array}$ \\
\hline P5 & $\begin{array}{ll}\checkmark & \text { Working as a welding advisor at JOTAC Academy } \\
\checkmark & \text { Expertise in welding more than } 40 \text { years } \\
\checkmark & \text { Experienced engineering engineer LTD in } 1977 \text { and worked } \\
& \text { with SIRIM in } 1980 \text { and became UITM (mechanical faculty) } \\
& \text { lecturer in } 2008 .\end{array}$ \\
\hline
\end{tabular}




\begin{tabular}{|c|c|}
\hline & $\begin{array}{l}\checkmark \text { Expertise in SMAW, GMAW, FCAW, GTAW, SAW, SW, welding } \\
\text { consultant and inospectery production of welding parameter } \\
\text { and bend geometry for } 40 \text { years } \\
\checkmark \quad \text { Approval of mechanical and master credentials in welding and } \\
\text { CSWIP } \\
\checkmark \text { Issuance of } 8 \text { techical papers on GMAW, FCAW, SAW, FW } \\
\checkmark \text { Supervisor to } 6 \text { master students and } 50 \text { bachelor degree } \\
\text { students. }\end{array}$ \\
\hline P6 & $\begin{array}{l}\text { \# Welding Lecturer in polytechnics } \\
\text { \# Skills in Welding } \\
\text { \# Experience teaching welding for } 7 \text { years } \\
\text { \# Specialist in arc welding, MIG and TIG for } 7 \text { years }\end{array}$ \\
\hline P7 & $\begin{array}{l}\text { Malaysian Polytechnic Welding Lecturer } \\
\text { Experience teaching welding (Arka, MIG and TIG) for } 12 \text { years } \\
\text { Expertise in arc welding, MIG and TIG } \\
\text { Graduated MLVK stage } 2 \text { welding. }\end{array}$ \\
\hline P8 & $\begin{array}{ll}\checkmark & \text { Malaysian polytechnic welding lecturer } \\
\checkmark & \text { TIG welding expertise and safety } \\
\checkmark & \text { Experience of TIG welding for } 16 \text { years } \\
\checkmark & \text { Approvals and certificates in } 3 \text { G and SMAW } \\
\checkmark & \text { Publishing of tungsten inert gas arc welding books (GTSBN- } \\
& 978-967-12450-03 \text { ) }\end{array}$ \\
\hline
\end{tabular}

Assessment of the validity of the content of the instrument was made using the questionnaire of the contents of the instrument which required the assessor to provide the answer in the form of fivepoint namely: (1) strongly disagree, (2) disagree, (3) disagree, (4) agree and 5) Strongly agree. The data were accurately analyzed using the prevalent method of accurately calculating the validity of instrumental content proposed by Tuckman. Tuckman stated that expert judgments that typically exceed the $70 \%$ coefficient value retain good content and have acquired a significant level of academic achievement. Effective instruments with a high content of validity will result in the achievement of the specific objectives that researchers want to accurately measure. The formula for score assessment is as follows:

$$
\frac{\text { Expert Score Amount }}{\text { Maximum Score }} \times 100 \%=\text { The achievement of the validity of the Content }
$$

\section{Data analysis}

The consistent findings of the criticality instinct of critical thinking in the TIG welding training module consist precisely of the overall content validity of the TIG Welding Training Modules based on the adaptation from the Student Activity Survey Form. As a result of the eight person expert 
INTERNATIONAL JOURNAL OF ACADEMIC RESEARCH IN BUSINESS AND SOCIAL SCIENCES

Vol. 9, No. 1, Jan, 2019, E-ISSN: $2222-6990$ ㄷ 2019 HRMARS

assessment, the value of the content validity of the TIG Welding Training Module can be seen in Table 2 below:

Table 2: Content Validity Overall by Item for TIG Welding Training Module

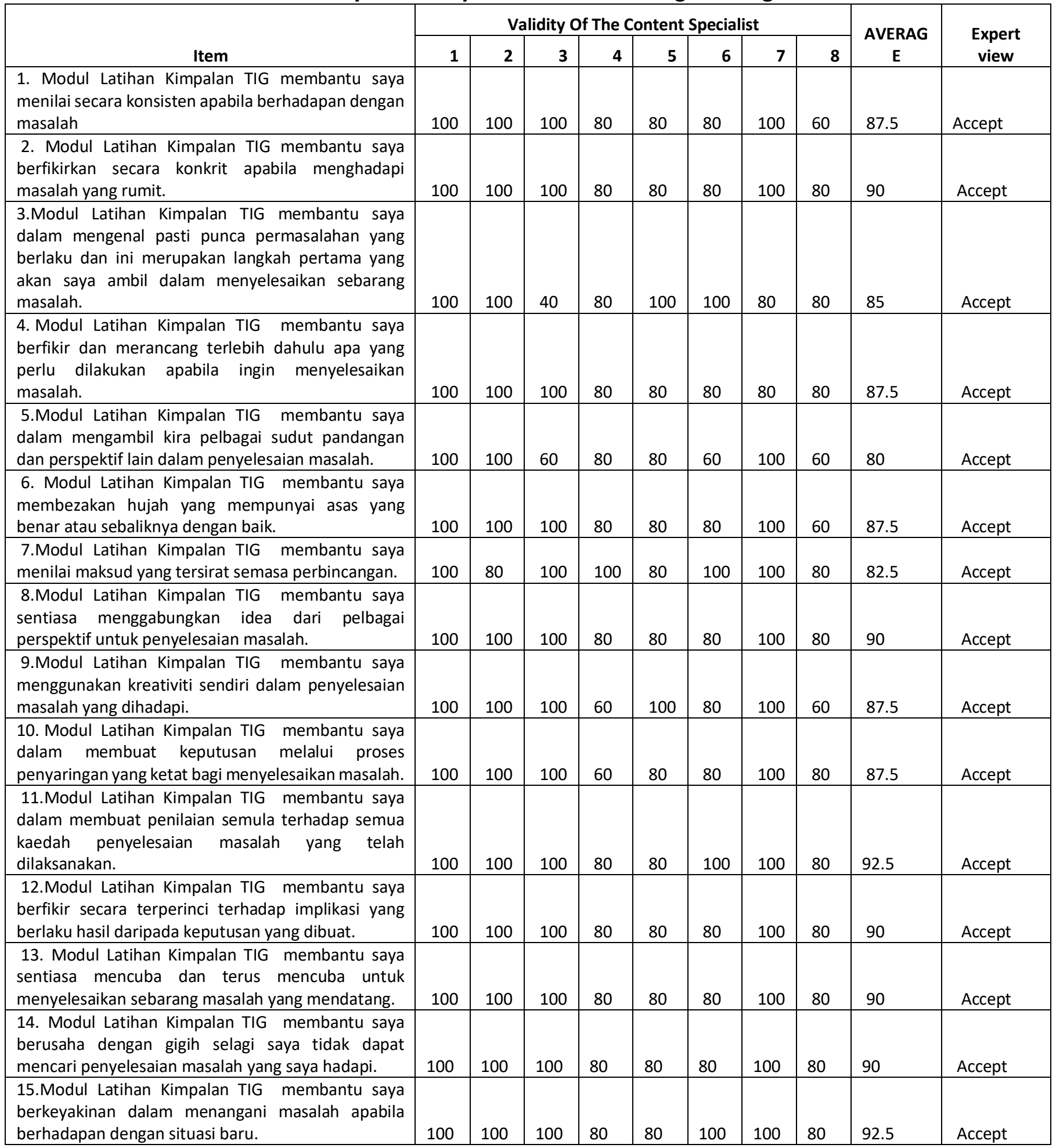


INTERNATIONAL JOURNAL OF ACADEMIC RESEARCH IN BUSINESS AND SOCIAL SCIENCES

Vol. 9, No. 1, Jan, 2019, E-ISSN: 2222-6990 @ 2019 HRMARS

\begin{tabular}{|l|l|l|l|l|l|l|l|l|l|}
\hline $\begin{array}{l}\text { 16.Modul Latihan Kimpalan TIG membantu saya } \\
\text { mengambil kira faktor persekitaran dalam } \\
\text { penyelesaian masalah. }\end{array}$ & & & & & & & & \\
\hline $\begin{array}{l}\text { 17. Modul Latihan Kimpalan TIG membantu saya } \\
\text { dalam memudahkan menyesuaikan diri dengan } \\
\text { pelbagai situasi. }\end{array}$ & 100 & 100 & 100 & 80 & 80 & 100 & 100 & 80 & 92.5 \\
\hline $\begin{array}{l}\text { 18. Modul Latihan Kimpalan TIG membantu saya } \\
\text { selesa bekerja dengan orang yang berbeza budaya. }\end{array}$ & 100 & 100 & 100 & 80 & 100 & 60 & 100 & 100 & 92.5 \\
Accept & Accept \\
\hline
\end{tabular}

Based on Table 2, the overall percentages for each specific item in the developed questionnaire were more than $80 \%$. The researcher found the lowest percentage was 80 percent for item five. The most significant percentages of the most significant content were 92.5 percent ie for items $11,15,16$ and 17 , this content indicates the validity of critical thinking instruments in the TIG Welding Training Modules is achieving high achievement levels. Therefore based on the general analysis of the percentage value is $88.61 \%$ more than $70 \%$. Tuckman (1981) stated that expert judgments that exceed the $70 \%$ coefficient value maintain good content validity and have acquired a high level of academic achievement. This means the level of validity of the critical thinking instrument in the TIG Welding Training Module is reliable and has a strong consistency. Put differently, the critical thinking technology of TIG Welding Training Modules based on Project Based Learning is believed to increase the critical thinking of Malaysian Polytechnic students. The expert panel's validity value is above.06 ie the minimum value set for acceptance.

\section{Conclusion}

The leading researcher successfully developed a critical thinking questionnaire instrument in the TIG Welding Training Module based precisely on a specific and complete Project Based Learning for Polytechnic Malaysia. The consistent findings of the criticality of the critical thinking media content show that the content of this specific intent is valid and of good quality and can be properly applied. It is expected that the critical thinking tools in the TIG Welding Training Modules will enhance the achievement of polytechnic students in turn to create human capital that will catalyze the development of the country later.

\section{Acknowledgement}

The authors wish to thank the Polytechnic Education Department of Higher Education Ministry of Malaysia for providing the data and Universiti Pendidikan Sultan Idris (UPSI) for funding this research under 2016-0139-107-01.

\section{Corresponding Author}

Md Kharul Bin Rakib, Department of Engineering Technology, Faculty of Technical and Vocational Education, Universiti Pendidikan Sultan Idris, 35900 Tanjung Malim, Malaysia,

Email: mdkharul87@gmail.com 
INTERNATIONAL JOURNAL OF ACADEMIC RESEARCH IN BUSINESS AND SOCIAL SCIENCES

Vol. 9, No. 1, Jan, 2019, E-ISSN: 2222-6990 (C) 2019 HRMARS

\section{References}

Abdullah, A. G. K., Ismail, A., Abdullah, M. H. and Purba, M. (2012). Acquired and required competencies in manufacturing sector graduates from employers" and employees. perspective: The Malaysian case Educ. Res. 2012 3(2): 126-136

Anastasi, A. dan Urbina, S. (1997). Psychological testing (7th ed.). New Jersey: Prentice-Hall.

Yahya, A., Sidek, S. \& Jano, Z. (2011). Critical Thinking Skills Among Final Year Students of Malaysian Technical Universities. Malaysian Technical Universities International Conference on Engineering \& Technology (MUiCET 2011). UTEM

Borang Soal Selidik Aktiviti Pelajar UPM (2011), Dokumen selepas Pelaksaan aktiviti, Borang mengikut keperluan prosedur pelaksanaan aktiviti oleh pelajar (muat turunhttp://www.hep.upm.edu.my) http://hep.upm.edu.my/upload/dokumen/20171202170754SLIDE AKTIVITI.pdf

Hairi, F. and Toee, A., Nazuir, A. and Razzaly, W. (2011), Employers" perception on soft skills of graduates: a study of Intel Elite soft skill training. In: International Conference on Teaching and Learning in Higher Education 2011 (ICTLHE2011) , 21-23 November 2011, Melaka.

Idris, N. (2013). Penyelidikan dalam pendidikan. McGraw-Hill Education.

Khan, S. U. (2015). The rise of "big data" on cloud computing: Review and open research issues. Information Systems, 47, 98-115.

Othman, M. S., \& Kassim, A. Y. (2018). Kesahan dan Kebolehpercayaan Instrumen Komposisi Pengajaran Guru Pendidikan Islam Sekolah Rendah yang Mengintegrasikan Kemahiran Berfikir Aras Tinggi (KBAT) Menerusi Pengajaran Akidah. Sains Humanika, 10(3).

Pallant J. (2007). SPSS Survival Manual. Sydney: Ligare Book Printer.

Noah, S. M. \& Ahmad, J. (2005). Pembinaan Modul : Bagaimana Membina $\quad$ Modul Latihan

Dan Modul Akademik. Penerbit Universiti Putra Malaysia.

Tuckman, B.W., \& Waheed, M.A. (1981). Evaluating an individualized science programmed for community college student. Journal of research in Science Teaching, 18, 489-495 